\title{
Living Strategies of the Urban Poor in a Local Town in Sarawak, Malaysia: Population Mobility of the Iban between Urban and Rural Areas
}

\author{
Ryoji SodA \\ Research Center for Regional Geography, Hiroshima University, \\ Higashi-Hiroshima 739-8522, Japan
}

\begin{abstract}
This paper examines the living strategies of the indigenous rural-urban migrants in Sarawak, Malaysia, by observing their social, economic, and political activities. In the study area, Sibu town, the population of the Iban increased rapidly in the 1980s locating mainly in squatter areas. Although their organizing ability was not strong, they did conduct profitable negotiations with the administration for their housing condition in cooperation with other ethnic groups. Consequently, they acquired new housing lots in a resettlement scheme, which helped them establish more stable lives in the urban area. However, most of them, including those employed in the formal sector, still intend to return home after retirement and maintain their various rights to property in home villages. Some urban dwellers have a flexible interpretation of their custom to remain as a member of the original village. The strong tie with home village community, however, does not necessarily shackle the urban dwellers. Their choice of staying in a local town is the core of their living strategies, which enable them to continue circulating between urban and rural areas, and make careful preparations for their future life after retirement.
\end{abstract}

Key words: Iban, Sarawak, Malaysia, living strategy, urban poor, circulatory migration, local town

\section{Introduction}

This paper focuses on the living strategies of rural-urban migrants in a local town in Malaysia.

On the basis of studies of out-migration and structural changes of indigenous villagers in Sarawak, Malaysia, the author finds many diverse migrant groupings. One of the findings is that in recent years more females are leaving their villages to follow their husbands who are employed in urban areas, which is one of the primary factors of structural change in rural communities (Soda 1999a). Family migration is also vital for urban population increase, because, whether they stay in illegal settlements or legal apartments, it is reasonable to think that those who are accompanied by their family are likely to stay longer compared to those who leave their family in their villages. Therefore, this paper focuses on family migration into urban areas to observe living strategies adopt- ed by the migrants, especially the so-called urban poor.

In this paper, the author does not attach much importance to the scale of cities nor population size, for rural-urban migrants now are not only in search of better economic opportunities, but also attracted to cities by a wide range of opportunities, consumption, education, and life styles. What is more important for them in cities, the author believes, is to approach persons or systems that can mediate between macro-societies and rural communities. In this sense, the author's standpoint in this paper has something in common with the viewpoint of urban anthropologists (Yoneyama 1987; Wazaki 1988).

In the following sections we will examine three main issues that effect rural to urban migrants: first, the emergence of squatter settlements and housing problems; second, migration patterns between rural areas and a small regional center; and third, migrants' strategies to keep the bonds with rural communities. These 
three issues reflect political, economic, and social aspects of rural-urban migrants' activities, respectively. Each of them, indeed, is a very important theme, but for the urban poor from rural areas, these three issues relate to each other and form the core of their strategies to keep rural-urban relations strong. However, there are very few comprehensive studies of these themes. This paper is a case study devoted to these issues particularly from the viewpoint of migrants themselves.

\section{Squatter Settlements and the Growth of Local Towns}

\section{The urban poor in local town ${ }^{1}$}

The emergence of squatter settlements or spontaneous settlements ${ }^{2}$ has been one of the major phenomena associated with the rapid population increase in Southeast Asian cities. For this reason much attention has been directed to those kinds of settlements in many urban centers, especially those in 'primate cities,' which have deepened our understanding of urban poverty. ${ }^{3}$ For example, the formation of home-based social networks in urban areas (Hugo 1981; Kato 1986) and their close relations to chain migration (Butterworth 1970; Yamazaki 1978; Niitsu 1989) are important. The higher rate of employment in the informal sector (Hart 1973; Tokman 1978; Jagannathan 1987; Nakanishi 1988a, b; Kumagai 1990) is also already considered as a common characteristic of the urban poor. Based on these understanding of the actual conditions of urban poverty there also have been lively discussions on the concepts of 'shared poverty' or 'urban involution' (McGee 1971).

Most of the early studies of squatters or the urban poor ${ }^{4}$ described the urban in-migrants themselves and their many social problems (Perlman 1976; Yonemura 1991a). Since the 1970 s, however, the emergence of the urban poor began to be discussed in the context of the marginality theory ${ }^{5}$ based on the dependency theory. The marginality theory argued that the urban poor were victims of a newly structured relation between the central capitalist world as the ruler and the marginal capitalist world as the ruled. ${ }^{6}$ This argument widely affected the studies on Southeast Asian cities paralleling the ideas of the modern world system theory presented by Wallerstein.

However, the discussion on urban inmigrants was not completely free from the tendency to define them as poor, stagnant, and marginalized people. ${ }^{7}$ On the contrary, recent empirical studies are much more positive, highlighting the initiative of urban in-migrants and their diverse living strategies. They touch on various topics such as the interaction with other (ethnic) groups in urban areas or administrative bodies, their practical use of the connection with social organization in the village of origin, and their contribution to the urban economy. ${ }^{8}$

But much of this research is on the urban poor in large cities. It was only in 1975 that Dwyer pointed out the fact that not only primate cities but all smaller cities and towns in Southeast Asia have squatters or spontaneous settlements mainly composed of rural-urban migrants (Dwyer 1975). It is unfortunate, therefore, that so far little attention has been paid to the in-migrants in local cities or towns. There seem to be some conceivable reasons.

First, there are statistical problems. Many scholars find even the official data or statistics of Third World countries are limited. This is particularly the case with statistical data on local cities or towns. These data are more difficult to use because of indistinct administrative boundaries of local cities or towns, frequent expansion of urban areas, and the lack of a consistent concept of 'urban' even within the same country.

Secondly, the problems of local towns hardly incite scholars to pay attention. Individually speaking, every local town has problems of urban poverty and housing shortage. Such problems, however, are not often recognized as emergency issues partly because of their peripheral location. If compared to the larger cities that often have large squatter problems even in the cores of the cities, spontaneous settlements in local towns tend to emerge on the fringe even in the early stage where the commuter distance is not so important because of the small scale of these secondary centers. 
Thirdly, the understanding of migration as economic activity leads to a neglect of local towns. Previous studies have attached more importance to larger cities regarding them as the final destinations of migration where migrants were supposed to enjoy more job opportunities and higher wages, while local towns were often considered just as relay points for migrants to larger cities.

Finally, these emphases upon migration to larger cities seem to satisfy a more macro viewpoint which gives priority to large urban centers. The study of migration to smaller cities and towns has been little researched and now needs more emphasis.

\section{Local towns in Sarawak}

So far, the Malaysian government has developed few clear policies for the urbanization of local towns. ${ }^{9}$
Table 1 shows the ranking of the cities and towns in Malaysia based on population. So long as we refer only to population size, urban centers in Sarawak are typical of local cities or towns in Malaysia in contrast to the primate city, Kuala Lumpur. However, in Malaysia, the Sarawak state has been rather peripheral both economically and politically on account of its historical background and geographical isolation $^{10}$. In particular, despite the Malaysian national target to promote industrialization and information technology, Sarawak is still dependent on the production and export of such raw materials as oil, gas, and timber. This imbalance in the economy has effected the employment structure, especially that of inmigrants from rural areas.

Another important point is that the ethnic composition in Sarawak is far different from that in peninsular Malaysia. According to the

Table 1. Population and number of households of major cities and towns in Malaysia, 1991

\begin{tabular}{|c|c|c|c|c|c|}
\hline State & City/Town Name & Population & Ranking & No. of Household & Ranking \\
\hline \multirow[t]{2}{*}{ Federal Territory } & Kuala Lumpur ${ }^{a}$ & $1,145,342$ & 1 & 244,267 & 1 \\
\hline & Labuan & 26,271 & 25 & 5,272 & 25 \\
\hline Johor & Johor Bahru ${ }^{a}$ & 328,436 & 2 & 70,032 & 2 \\
\hline Kedah & Alor Star & 124,412 & 10 & 25,385 & 8 \\
\hline Kelantan & Kota Bharu & 58,335 & 24 & 11,853 & 24 \\
\hline Melaka & Melaka & 75,909 & 20 & 15,282 & 19 \\
\hline Negeri Sembilan & Seremban & 72,958 & 21 & 14,771 & 20 \\
\hline Pahan & Kuantan & 86,360 & 15 & 17,724 & 14 \\
\hline \multirow[t]{2}{*}{ Perak } & Ipoh $^{\mathrm{a}}$ & 301,424 & 3 & 67,512 & 3 \\
\hline & Taiping & 62,321 & 23 & 12,820 & 22 \\
\hline Perlis & Kangar & 14,247 & 26 & 2,978 & 26 \\
\hline \multirow[t]{5}{*}{ Pinang } & Seberang Perai (Tenggah) & 236,270 & 4 & 47,739 & 4 \\
\hline & Georgetown & 219,603 & 5 & 43,456 & 5 \\
\hline & Pulau Pinang (Barat Daya) & 122,764 & 11 & 24,892 & 10 \\
\hline & Seberang Perai (Selatan) & 84,771 & 17 & 16,383 & 16 \\
\hline & Butterworth & 78,640 & 18 & 15,864 & 18 \\
\hline \multirow[t]{3}{*}{ Sabah } & Sandakan & 125,841 & 9 & 21,666 & 11 \\
\hline & Tawau & 86,289 & 16 & 16,263 & 17 \\
\hline & Kota Kinabalu & 76,120 & 19 & 14,481 & 21 \\
\hline \multirow[t]{3}{*}{ Sarawak } & Kuching (Selatan/Utara) & 148,059 & 7 & 26,748 & 7 \\
\hline & Sibu & 126,381 & 8 & 25,275 & 9 \\
\hline & Miri & 87,167 & 14 & 17,358 & 15 \\
\hline \multirow[t]{3}{*}{ Selangor } & Klang & 161,773 & 6 & 30,347 & 6 \\
\hline & Shah Alam & 102,019 & 12 & 20,392 & 12 \\
\hline & Bandar Petaling Jaya & 88,338 & 13 & 18,464 & 13 \\
\hline Terengganu & Kuala Terengganu & 67,027 & 22 & 12,464 & 23 \\
\hline
\end{tabular}

a a place with city status

Cities and towns with municipal status are listed. The population outside urban areas (bandar/pekan) is not counted.

Source: Population Report for Local Authority Areas 1991. 
1991 census, the population of Sarawak is $1,642,771$ comprised of various ethnic groups such as Iban, Chinese, Malay, Bidayuh, Melanau, and other smaller groups. ${ }^{11}$

In Malaysia, there is another unique 'ethnic' category called 'Bumiputera' (literally sons of the soil), which is an administrative and political term to clearly distinguish the 'indigenous' peoples from the 'non-natives,' such as the Chinese or the Indian who have mostly migrated into Malaysia since the colonial period.

In Peninsular Malaysia, the term Bumiputera is normally used for Malays and Orang Asli groups. In Sarawak, on the other hand, it includes Malays, Ibans, Bidayuhs, and all other small ethnic groups. The Bumiputera Policy, ${ }^{12}$ which came into force in 1971, is an affirmative action plan to propel poorer indigenous people into the economic mainstream. In the context of Sarawak politics, however, the priority as the Bumiputera is undoubtedly given to the Muslim-Bumiputera, and therefore, it is useful to classify the population into three categories, namely, Muslim Bumiputera, non-Muslim Bumiputera, and non-Bumiputera in Sarawak. If categorized in accordance with this criterion, Muslim Bumiputera comprise 27.4\%, non-Muslim Bumiputera 43.2\%, and nonBumiputera $29.2 \%$. In urban areas, however, non-Bumiputera (50.7\%) outnumber the other two groups (Muslim Bumiputera 28.9\%, nonMuslim Bumiputera 19.9\%).

This paper, draws on the author's previous research work on the rural Iban communities, but deals with in-migrants into urban areas, especially squatters and their resettled community of the Iban, the dominant ethnic group within the non-Muslim Bumiputera. The Iban are known as shifting cultivators who, so long as they are in the home village, live in a kind of communal house (called long-house) in which plural families live together. Despite its predominance as the largest single ethnic group in Sarawak, the relative economic situation of the Iban seems to be becoming harsher with respect to employment opportunities, housing policy, or loan treatment compared to Muslims, who have been given preferential treatment since 1963 when Sarawak joined Malaysia. Thus Ibans, despite a strong sense of their own cul- tural identity, have been excluded from the mainstream of government development programs. In short, as 'Sarawakians' in the national context of Malaysia and as non-Muslim Bumiputera in the regional context of Sarawak, the Iban are burdened with 'double marginality. ${ }^{13}$ Considering this situation of the Iban is essential in order to understand their internal migration. ${ }^{14}$

\section{Setting and fieldwork}

The field research of this study was carried out in Sibu town, the regional center of the Rajang basin (see Figure 1). It has developed chiefly due to its timber-based industry to become the second largest town in Sarawak (1991 census). The author has been conducting research on the out-migration from long-houses of the Iban and its impact on their communities in the middle reaches of the Rajang where there is a large population of Iban. In a previous paper the author pointed out that the family out-migration from rural areas had been increasing remarkably and their most important destination was neither the metropolis nor the state capital but the neighboring local town, Sibu (Soda 1999a).

The reason why Sibu town is chosen as the research site is not just because of Sibu's economic and social importance for the Iban who live in the Rajang basin, but also because Sibu has become a place where the Iban are experiencing the realization of their greater marginality through interactions with other ethnic groups or the urban administration. Sibu has a significant community of Chinese. In 1901 Foochow group from China began to migrate into Sibu under the sponsorship of the Brooke Government because the area was expected to become a paddy-planting center. Until the present Sibu has been known as a Foochow dominated area. ${ }^{15}$

In 1925 the Sibu Municipal Board (SMB) was formed and Sibu town was defined as a regional center of the then third division (which included present Sibu division). The defunct SMB was taken over to Sibu Urban District Council (SUDC) to become autonomous in 1952. The area of SUDC was then about 7.8 square kilometers. The 1947 census indicated a popu- 


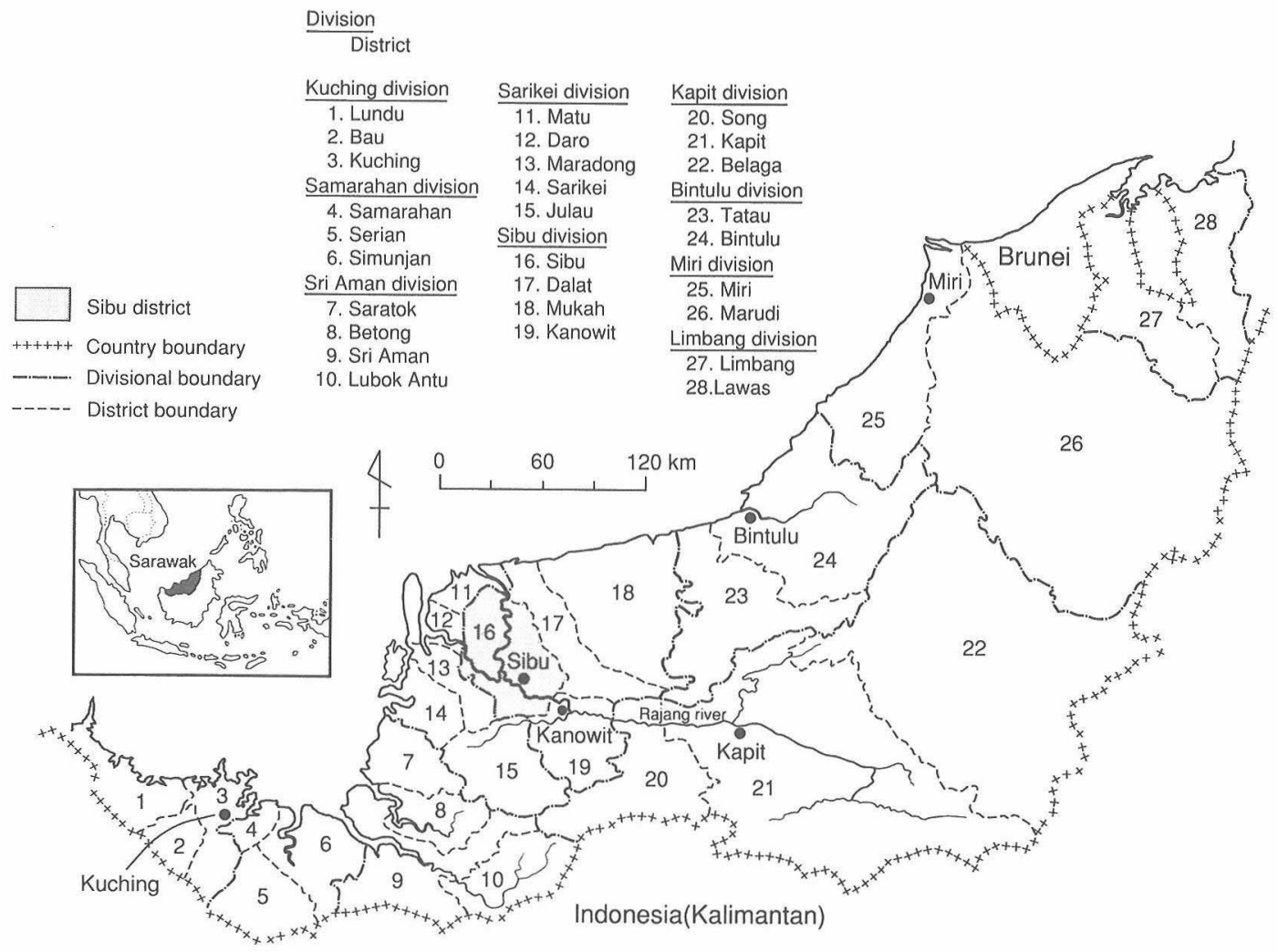

Figure 1. Map showing administrative districts in Sarawak.

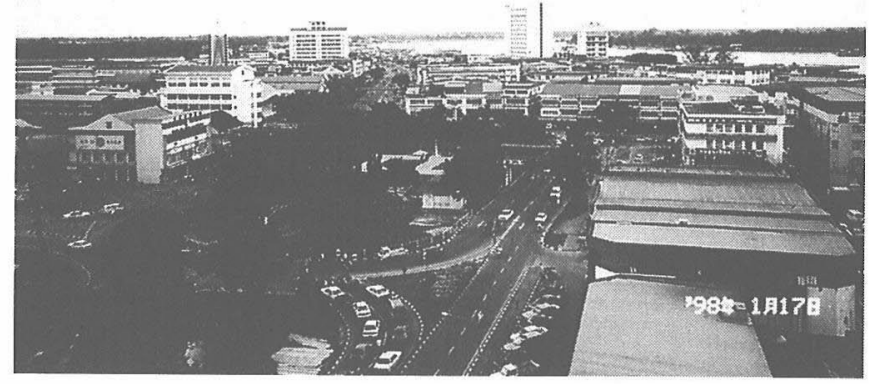

Photo 1. Sibu town.

lation of 9,983 in the Sibu Municipal District. In 1957 the Sibu Urban District boundary had been extended and contained a total area of approximately 51.8 square kilometers. The population was 29,630 as of 1960 according to the 1960 census. The SUDC was restructured and upgraded to Sibu Municipal Council in 1981 with areas extended to 129.5 square kilometers. According to the 1991 census, the population of Sibu was 126,381 comprised of 


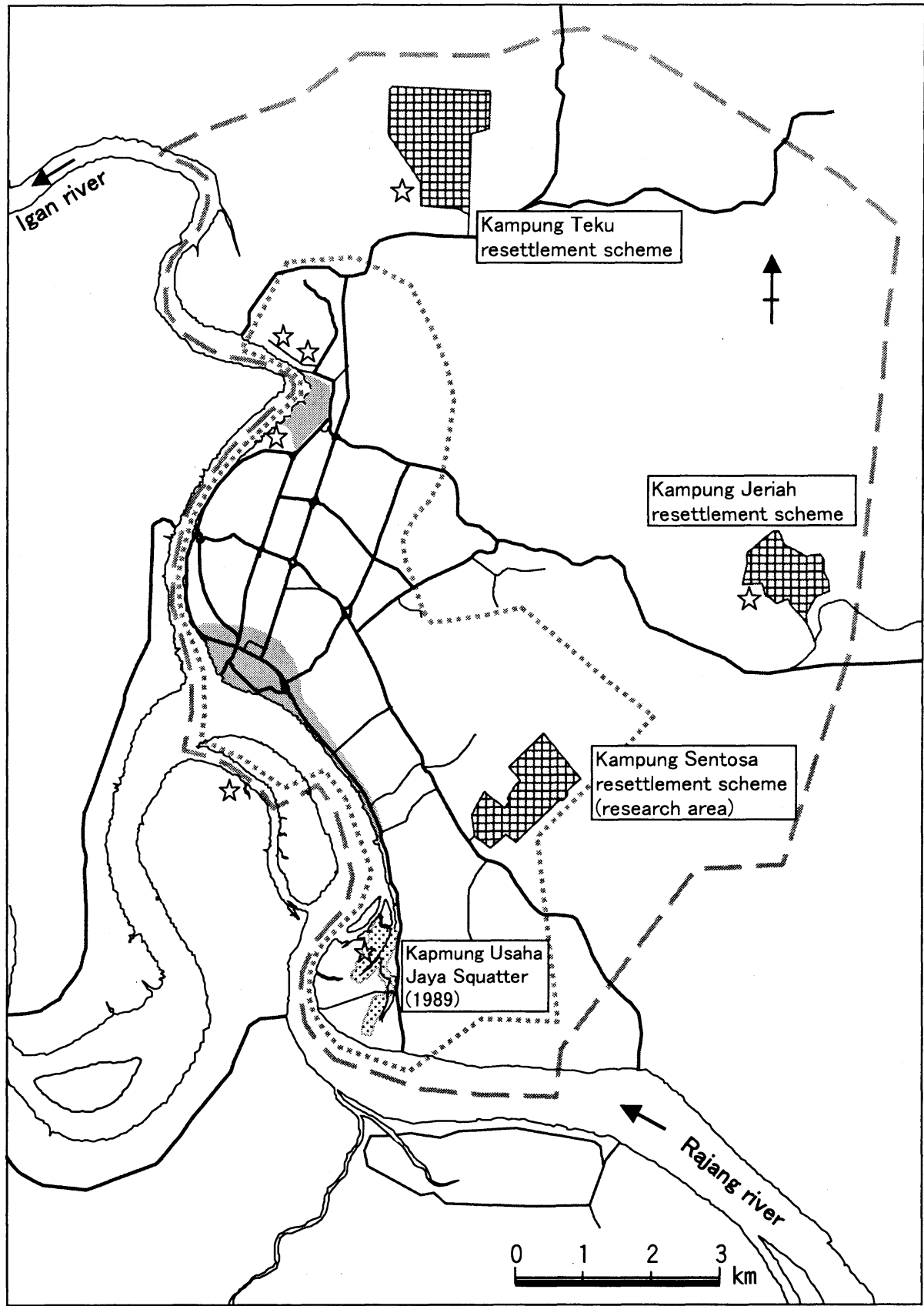

Town center

. Defunct Sibu urban district boundary (fixed in 1957) Existing Sibu municipal
boundary (fixed in 1981)
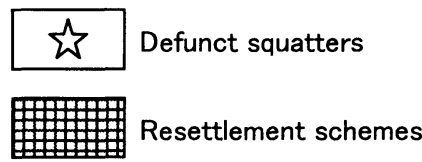

\% Kampung Usaha Jaya squatter

Figure 2. Study area and its surroundings. 
Table 2. Number of buildings in squatter areas in Sibu town

\begin{tabular}{|c|c|c|c|c|}
\hline Squatters area & Malay/Melanau ${ }^{\mathrm{a}}$ & Iban $^{\mathrm{b}}$ & Chinese $^{c}$ & Total \\
\hline Kampung Usaha Jaya, Upper Lanang & 633 & 605 & 172 & 1,410 \\
\hline Sungai Pakan, Loba Kerto & 5 & 18 & 0 & 23 \\
\hline Batu 6, Jalan Sibu/Oya & 311 & 121 & 6 & 438 \\
\hline Sungai Antu & 6 & 125 & 1 & 132 \\
\hline Sungai Teku & 5 & 0 & 0 & 5 \\
\hline Kampung Nyamuk, Jalan Igan & 103 & 3 & 14 & 120 \\
\hline Rumah Eroke & 0 & 32 & 0 & 32 \\
\hline Total & 1,063 & 904 & 193 & 2,160 \\
\hline $\begin{array}{l}\text { equivalent to Muslim Bumiputera } \\
\text { equivalent to Non-Muslim Bumiputera } \\
\text { equivalent to Non-Bumiputera } \\
\text { ource: Land and Survey Department, Sibu di }\end{array}$ & & & & \\
\hline
\end{tabular}

Chinese (66.7\%), Iban (13.4\%), Malay (10.5\%), Melanau (7.1\%), Bidayuh (0.7\%), and others $(0.6 \%)$.

In Sarawak there is a stereotype about the correlation between ethnicity and the employment sector as follows: the business sector for Chinese (non-Bumiputera), the government sector for Malay/Melanau (Muslim Bumiputera), and the informal sector or unskilled labor sector for other indigenous groups (non-Muslim Bumiputera). Ethnic composition in Sibu town ${ }^{16}$ apparently coincides with such a stereotype. In this point, too, the squatters in Sibu can be appropriate subjects for an inquiry into the marginal situation of the Iban in-migrants into urban areas.

The research was mainly conducted from June to September 1999. Additional fieldwork was carried out in January 2000. This paper uses survey data as of September 1999 unless otherwise noted.

\section{Squatters, Migrants, and Housing}

\section{Squatter settlements in Sibu town}

In Sibu the squatters are said to have increased rapidly since the end of the 1970 s to the 1980s (Sutlive 1992). According to the research conducted by the Land and Survey Department, at least seven major squatter settlements have emerged within Sibu town since the second half of the 1970s. Figure 2 shows the locations of the settlements, most of which are situated near the town boundary. Table 2 shows the estimated number of illegal houses and the approximate ethnic composition in each settlement. The growth in squatter numbers provoked action by the Sarawak government. The main measure by the government toward squatters in the 1980s and the early 1990s was to issue Temporary Occupation Licenses (TOLs) to squatters and the urban poor. This license permitted the urban poor and squatters to occupy a piece of land in a resettlement area for up to a sixty-year time limit. In Sibu town there are now three resettlement areas where TOLs are issued to the squatters or the urban poor (Figure 2).

In Kampung Jeriah resettlement scheme, TOLs were given to those who have already squatted there. Without adequate readjustment of lots nor segregation planning, Muslims and non-Muslims are mixed in the area, which leads to complaints among the residents. ${ }^{17}$ Kampung Teku resettlement scheme is a planned settlement constructed to provide segregation areas for the three groups: Muslim Bumiputera, non-Muslim Bumiputera, and nonBumiputera. The area includes not only the former squatters from various areas in Sibu but also new migrants from neighboring villages.

The newest resettlement area is Kampung Sentosa. This scheme also has a deliberate ethnic segregation and almost all of its residents are former squatters from Kampung Usaha Jaya area, which was the largest squatter settlement in Sibu. According to the report of the Land and Survey Department, altogether in these three resettlement schemes 2,394 lots 


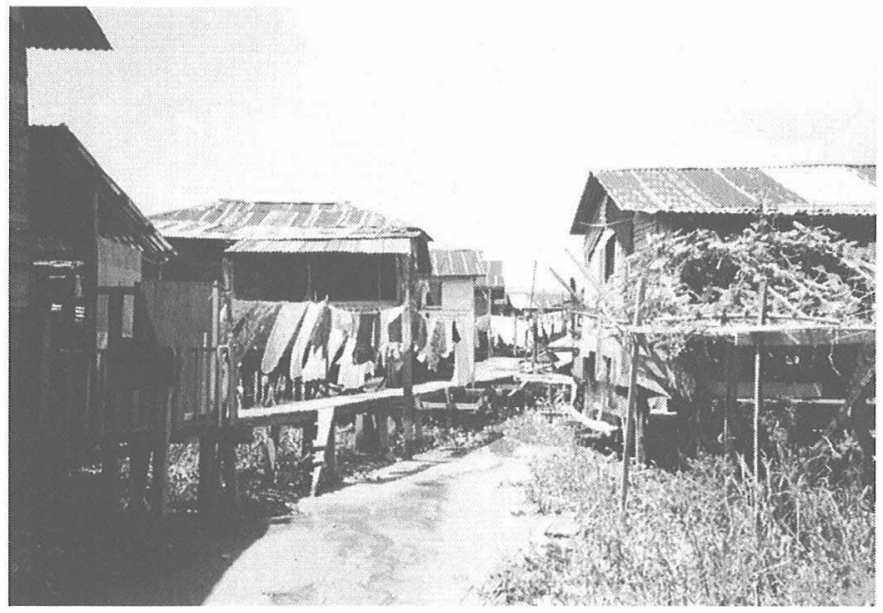

Photo 2. Kampung Usaha Jaya squatter (July 1996).

In 1996 there still existed a number of squatters who had not yet built a new house in the resettlement area.

have already been allocated as of 1998 and an additional 368 lots are supposed to be allocated in the near future.

The argument on the present situation of the Iban that follows is mainly based on the data which were gathered through interviews with Kampung Sentosa residents (85 households in Phase 1 and 47 households in Phase 2). All the registered household heads who were interviewed are non-Muslim Bumiputera (mostly Iban). Although the number of interviewees is limited because of various restrictions, the data shown here are believed to represent general features of the Iban 'urban poor' who have migrated in the urban and remain there with their families.

\section{The growth of Kampung Usaha Jaya and population composition}

Kampung Usaha Jaya squatter settlement (hereafter called $\mathrm{Kg}$. UJ) came to be established on the bank of Rajang river. It was said that in the second half of the 1970s some Malays and Melanaus (Muslim Bumiputera) began to squat in this area, and were followed by the Iban particularly in the early 1980 s, when the squatter area had already expanded considerably (Figure 3). There is no accurate data on the growth of the squatter settlement except for occasional reports of the Land and Survey Department. According to the research of the Department in September 1982, Kg. UJ settle- ment was made-up of Malay/Melanau (193 households), Iban (101 households), and Chinese (105 households), while the annual report of 1989 showed the ethnic composition of the households as 621 Malay/Melanau, 438 Iban, and 158 Chinese. The population composition immediately before the resettlement scheme (1991) was 633, 605, and 172 respectively.

As for the Iban, Table 3 indicates that most of them came to $\mathrm{Kg}$. UJ in the 1980s. It should be noted that $57.6 \%$ of the registered household heads of Kampung Sentosa, when interviewed, reported that they had lived in rented rooms or houses in Sibu town before moving to $\mathrm{Kg}$. UJ. According to this table, $83.3 \%$ of them had already been in Sibu before coming to $\mathrm{Kg}$. UJ. Those who came to $\mathrm{Kg}$. UJ directly from towns in other districts and from long-houses are only $2.3 \%$ and $12.1 \%$ each. Their average age at the time of first migrating into Sibu town was 26.0 years old. On the contrary, their average age at the time of moving to $\mathrm{Kg}$. UJ was 32.9 years old, and $90.9 \%$ of them were married and accompanied by their family.

The employment rate of the household heads when they first came to Sibu was $91.7 \%$, of which government servants occupied $37.1 \%$. The employment rate slightly rose to $93.2 \%$ $59.8 \%$ of government servants - when they moved to $\mathrm{Kg}$. UJ (Table 4). ${ }^{18}$ These figures indicate that most of the squatters in $\mathrm{Kg}$. UJ did not necessarily suffer extreme poverty, but had 


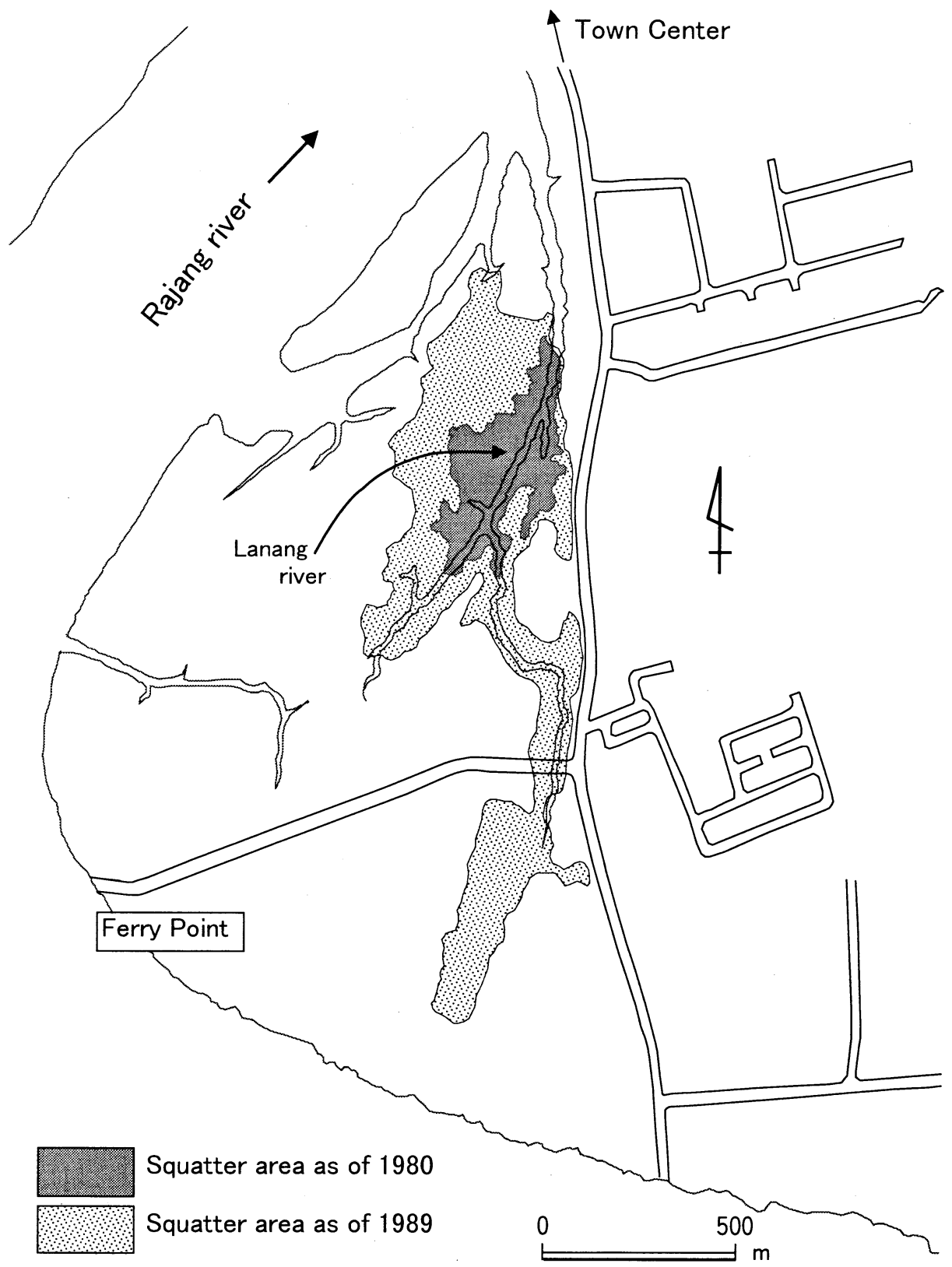

Figure 3. Expansion of Kampung Usaha Jaya squatter area.

Sources: Aerial photographs, Sortie 8/80, Sibu Town, Scale $1: 10,000,1980$. Aerial photographs, Sortie 3/89, Sibu Town, Scale 1:10,000, 1989.

already experienced rather steady urban lives.

According to the interviews, they had three major reasons for their move from rented rooms (or houses) to the squatter area. First, the rate of room-rent rise exceeded that of wage-hike. Secondly, the increase in family members resulting from marriage and child- birth made their living space insufficient. Thirdly, the growth of their children began to burden them with food and educational expenses besides room-rent. In addition, those who were then government servants pointed out the shortage of government quarters for them. 
Table 3. Year when the interviewed persons moved to Kampung Usaha Jaya and their previous residence

\begin{tabular}{|c|c|c|c|c|c|c|c|c|c|c|}
\hline \multirow{3}{*}{$\begin{array}{l}\text { Year of } \\
\text { move to } \\
\text { Kampung } \\
\text { Usaha } \\
\text { Jaya }\end{array}$} & \multicolumn{10}{|c|}{ Previous residence } \\
\hline & \multicolumn{5}{|c|}{ Sibu Town } & \multicolumn{2}{|c|}{ Long-house } & \multirow{2}{*}{$\begin{array}{l}\text { Other } \\
\text { towns }\end{array}$} & \multirow[b]{2}{*}{ Unknown } & \multirow[b]{2}{*}{ Total } \\
\hline & $\begin{array}{c}\text { Rented } \\
\text { room }\end{array}$ & $\begin{array}{c}\text { Government } \\
\text { quarters }\end{array}$ & $\begin{array}{c}\text { Company } \\
\text { barrack }\end{array}$ & $\begin{array}{c}\text { Relative's } \\
\text { house }\end{array}$ & $\begin{array}{l}\text { Others/ } \\
\text { unknown }\end{array}$ & $\begin{array}{c}\text { Sibu } \\
\text { district }\end{array}$ & $\begin{array}{c}\text { Other } \\
\text { districts }\end{array}$ & & & \\
\hline Before 1979 & 2 & 2 & & 1 & & 1 & & & & 6 \\
\hline 1980 & 8 & & & & 3 & & & & & 11 \\
\hline 1981 & 15 & 4 & & & 3 & 2 & & & & 24 \\
\hline 1982 & 9 & 2 & & 1 & 1 & 3 & & & & 16 \\
\hline 1983 & 3 & 1 & 1 & 1 & 1 & 1 & 2 & & & 10 \\
\hline 1984 & 11 & & & & 1 & 2 & & & & 14 \\
\hline 1985 & 8 & 4 & 1 & 1 & & & & & & 14 \\
\hline 1986 & 5 & & 1 & & & 1 & & & & 7 \\
\hline 1987 & 5 & & & 1 & 2 & 3 & & & & 11 \\
\hline 1988 & 3 & & & & 1 & & 1 & 1 & & 6 \\
\hline 1989 & 4 & & & & & & & & & 4 \\
\hline 1990 & 2 & & & & & & & & & 2 \\
\hline After 1991 & & & & & 1 & & & 2 & & 3 \\
\hline Unknown & 1 & & & & & & & & 3 & 4 \\
\hline Total & 76 & 13 & 3 & 5 & 13 & 13 & 3 & 3 & 3 & 132 \\
\hline
\end{tabular}

Source: Author's field survey.

Table 4. Year when the Kampung Sentosa residents came to Sibu and their working situation at the time

\begin{tabular}{lccccc}
\hline & $\begin{array}{c}\text { Government } \\
\text { Sector }\end{array}$ & $\begin{array}{c}\text { Private Sector } \\
\text { Self-employed }\end{array}$ & Unemployed & Others/Unknown & Total \\
\hline Before 1960 & 1 & 3 & 0 & 0 & 4 \\
$1961-1970$ & 14 & 10 & 0 & 0 & 24 \\
$1971-1980$ & 25 & $21(1)$ & 3 & 0 & 65 \\
$1981-1990$ & 6 & 2 & 0 & 0 & 30 \\
After 1991 & 1 & 0 & 0 & 4 & 3 \\
Unknown & 2 & 72 & 7 & 4 & 6 \\
\hline Total & 49 & & & 132 \\
\hline
\end{tabular}

( ): Self-employed

Source: Author's field survey.

Compared to other squatters in Southeast Asian countries, those who lived in $\mathrm{Kg}$. UJ were conspicuous for their higher employment rate, especially those in the government sector. The large number of government servants seems related to the so-called 'Bumiputera policy'; this policy is a popular name for the 'New Economic Policy (NEP)' formulated under the Second Malaysia Plan (1971-1975) which was a type of affirmative action intended to raise the economic standard of vulnerable indigenous peoples in Malaysia. ${ }^{19}$ Although the quota system at the lower echelons of the administration is not institutionalized, there are many
Ibans who perceive that they have had the benefit of their status as government servants from the Bumiputera policy. This perception may be based on the fact that the working rate of Ibans in the study area had improved particularly in the government sector from the 1970 s to the 1980s (see Table 5).

However, they are also conscious that the Iban are provided with employment opportunities only in non-clerical or blue-collar section, and that the Malay/Melanau (Muslim Bumiputera) have preference in government jobs compared to the Iban despite their similar educational background or work experiences. 
Table 5. Working situations of household heads in Kampung Sentosa at each period

\begin{tabular}{lcccccc}
\hline & \multicolumn{5}{c}{ Working situation } \\
\cline { 2 - 7 } & $\begin{array}{c}\text { Government } \\
\text { Sector }\end{array}$ & $\begin{array}{c}\text { Private } \\
\text { Sector }\end{array}$ & Self-employed & Unemployed & Unknown & Total \\
\hline When came to Sibu town & 49 & 70 & 2 & 7 & 4 & 132 \\
When came to Kampung Usaha Jaya & 79 & 41 & 3 & 5 & 4 & 132 \\
When came to Kampung Sentosa & $83^{\mathrm{a}}$ & $35^{\mathrm{b}}$ & 6 & 5 & 3 & 132 \\
\hline a including 5 pensioners and 1 deceased & & & & & \\
b including 2 deceased & & & & & & \\
Source: Author's field survey. & & & & & &
\end{tabular}

Most of the Iban express their grievance-sometimes with resignation-against the discrimination between Muslim and non-Muslim even within the Bumiputera status.

In urban centers in Sarawak, housing supply measures for these low-income groups have had very little emphasis compared to job creation. While the fruit of Bumiputera policy, at least in the study area, has been reflected in the expansion of employment opportunities in the government sector, the supply of government quarters has been so poor that lower-class government servants rarely obtain the chance to be provided with quarters. Since non-clerical work, in particular, is dominated by nonMuslim Bumiputera in-migrants such as the Iban from the interior, job creation and housing supply should be considered a linked problem. In short, as is pointed out by the former $\mathrm{Kg}$. UJ residents themselves, it can safely be said that the squatter settlements in Sibu resulted from the imbalance between job-creation and housing policies.

\section{The subject of the formulation of resettle- ment plan}

The Sarawak government's policy of squatter removal in the latter half of the 1980 s was to provide the squatters with housing lots in new resettlement areas with the issue of provisional land title called 'Temporary Occupation License (TOL). ${ }^{20}$ In order to obtain a new lot and its TOL in a resettlement area, each squatter was required to make an application by himself and had to meet conditions indicated in Table $6{ }^{21}$ On acquisition of a new lot, the applicants were required to pay a handling charge (called 'premium') by installments. Concerning the premium of the lots in Phase 1, though the premium ranged from 4,900 Ringgit Malaysia ${ }^{22}$

Table 6. Prerequisites to apply for a lot in resettlement area

$$
\text { Condition }
$$

1 An applicant must be acknowledged as a squatter by the staff of the enforcement section of the Land and Survey Department.

2 The hut of the applicant concerned must have been examined and registered by the Land and Survey Department.

3 The hut concerned must be possessed by the applicant himself.

4 An applicant who has long rented a hut in the squatter area to live there has rights to apply for a lot in the resettlement area.

5 An applicant must meet the condition that (s)he has no land for residence within 3 miles radius from the resettlement area provided by the Land and Survey Department.

6 An applicant must have Malaysian citizenship.

$7 \quad$ An applicant must have a family.

8 A female squatter over 21 years old who has children though has already been divorced from or bereaved of husband. 
(400 square meters) to 14,210 Ringgit Malaysia (1,160 square meters) according to the area of the lots, these prices were extremely low in comparison with ordinary purchase prices of land. They are supposed to be given formal land titles ${ }^{23}$ after paying $10 \%$ of the premium.

In the mid-1980s seven squatter areas were observed in Sibu. The Land and Survey Department proposed resettlement schemes of some squatter communities, and the scheme presented to $\mathrm{Kg}$. UJ residents in 1984 was to move to Kampung Jeriah (hereafter called $\mathrm{Kg}$. Jeriah) resettlement scheme. It is noteworthy that the $\mathrm{Kg}$. UJ residents were united in refusing to resettle in $\mathrm{Kg}$. Jeriah because the new settlement was farther from the town center than Kg. UJ. Although the Sarawak government had intended to make $\mathrm{Kg}$. UJ residents and those who had already squatted nearby $\mathrm{Kg}$. Jeriah resettle in $\mathrm{Kg}$. Jeriah, the consensus of $\mathrm{Kg}$. UJ residents led the government to withdraw the initial plan. Consequently, the government issued TOLs only to those who had already squatted in nearby $\mathrm{Kg}$. Jeriah without any systematic readjustment of the lots.

It is further interesting to note that an alternative resettlement plan was submitted in 1988 by $\mathrm{Kg}$. UJ residents themselves, not by the government. ${ }^{24}$ When they refused the government's initial scheme and afterwards presented the new plan to move to Bukit Lima (existing Kampung Sentosa), the major role was played by the then informal organization called 'Jawatankuasa' (literally committee). Jawatankuasa had been organized among each group of Muslim Bumiputera, non-Muslim Bumiputera, and non-Bumiputera. The committee members of each Jawatankuasa group had cooperated with each other in meetings on their resettlement scheme.

This organizing ability of squatters deserves attention. While there are many studies on the informal organization of the urban poor (or squatters), most of them point out the importance of homeland-based organization for mutual aid. Some of them even declare that the foundation of the associations organized by the urban in-migrants can be attributed to common backgrounds or their kinship, and not just ethnicity. But the importance of homeland- based, or kinship-based organizations, is tacitly emphasized on the premise that there is a considerably large population in the original villages of squatter residents. As for the case of the Iban or other non-Muslim Bumiputera in Sarawak, however, the scale of their village is rather small because their village communities are usually organized in the form of 'longhouse,' a kind of communal house. ${ }^{25}$ The small population of the home village (long-house) hardly gives them the opportunity to compose homeland-based associations in urban areas.

Actually, although the Iban of $\mathrm{Kg}$. UJ did not have any strong ethnic-based or homelandbased organizations, they had a means to achieve the collective support of the Iban residents through the loosely organized Jawatankuasa committee. Moreover, through each Jawatankuasa organization of the Malay/ Melanau (Muslim Bumiputera), the Chinese (non-Bumiputera), and the Iban (non-Muslim Bumiputera), there was cooperation between them, which served a certain function on the issue of resettlement scheme, which was considered to be of primary importance by the $\mathrm{Kg}$. UJ residents themselves. Particularly from the standpoint of the Iban (non-Muslim Bumiputera), inter-ethnic cooperation was indispensable. A then committee member of Jawatankuasa asserted that, under the conditions of the Muslim preferential policy in the national context and the predominance of the Chinese in Sibu town, the Iban had a consensus view that it would be very difficult for the Iban to advance their own interests without cooperation and compromise with other ethnic groups. It can be safely said that this consensus view on ethnic composition was a factor that enabled the solidarity of different ethnic groups.

Another remarkable point, as mentioned earlier, was the large number of government servants among the Bumiputera in $\mathrm{Kg}$. UJ, among whom were included staff of the Land and Survey Department, the Public Works Department, the Sibu Municipal Council, and other related government agencies. According to a then Jawatankuasa committee member, they could obtain sufficient information through these government staff to search for a 
suitable area for the construction of a resettlement scheme and estimate its feasibility. What is more, most migrants to Kg. UJ since 1985 had already acquired some information as to the proposed resettlement project and moved into Kg. UJ in the expectation of the possibility of being given new lots free of charge by the government.

In short, although they were not formally organized, $\mathrm{Kg}$. UJ residents were endowed with considerable ability at organizational activities and information gathering. And furthermore, Jawatankuasa committee members obtained a chance to reach the negotiation table directly with the then Land Minister of Sarawak and made a political deal ${ }^{26}$ prior to the implementation of the resettlement scheme. Their interaction with the government or the administration shows their diverse strategies to realize stable urban lives. In the following section, details of their present urban lives will be observed.

\section{Economic Aspects of Migration to Local Town}

\section{Origin of Kampung Sentosa residents and their working situation}

The new resettlement scheme, Kampung Sentosa (hereafter called Kg. Sentosa) has two phases. According to the issued Temporary Occupation Licenses, Phase 1 is composed of 246 households of Malay/Melanau (Muslim Bumiputera), 151 of Iban (non-Muslim Bumiputera), and 94 of Chinese (non-Bumiputera), while in Phase 2, there were 247, 268, and 71 households of each. In both phases, residential areas of each ethnic group are clearly segregated as shown in Figure 4.

Resettlement of those who had obtained TOLs in Phase 1 was implemented in 1991 and is now almost complete, while resettlement in Phase 2 brought in to effect in 1996 has not yet been accomplished as of this writing and most of the houses in Phase 2 are still under construction. $^{27}$ Besides them, there are lots which have not yet been allocated and land for the government reserve in Phase 2.

Through personal interviews in the nonMuslim Bumiputera area, data for 132 households (85 households in Phase 1 and 47 in Phase
2) were obtained. Figure 5 shows the age structure of the interviewed household heads and their current family members, according to which the average age of the household heads was 48.1 years old. The average number of household members was 6.0 , including $52.3 \%$ of conjugal (or nuclear) families, $30.3 \%$ of stem families, $12.9 \%$ of joint families, and $4.5 \%$ of other types. ${ }^{28}$

Figure 6 shows the routes of the move of the registered household heads and their spouses from their home to Sibu. The figure indicates that their home places are dispersed in rural areas around Sibu town and not necessarily concentrated in a specific region. Most of their home places, however, are located within a 100kilometer radius from Sibu town, and it can be inferred that Sibu does not draw long-range migration from farther rural areas but exists as a regional center in the Rajang basin.

The main purpose of the first migration into Sibu town was to seek jobs, ${ }^{29}$ but unlike the squatters studied in other Third World countries, most of the Iban of Kg. Sentosa answered that before their move into Sibu town they had already been assured of a job on the introduction of their acquaintance, or at prior interviews with their employers. The working situation of registered household heads when they first came to Sibu town is shown in Table 4. Those who had obtained jobs in the government sector were $37.1 \%$, and those in private sectors including self-employed were $54.5 \%$, of which $23.5 \%$ were contract workers.

The job situation of registered household heads in the research period ending in September 1999 indicates the relative increase of employees (including pensioners) in the government sector (see Table 5). As for the occupations of current households' members, as is indicated in Table $7,{ }^{30}$ those who work in the government sector account for 39.5\% (male: $43.3 \%$, female: $28.8 \%$ ), while the major occupations in private sectors are factory workers, various kinds of drivers, and construction laborers, and those in the category of selfemployment are mostly taxi drivers and food sellers.

Those who are categorized in the government sector here are mostly engaged in such non- 


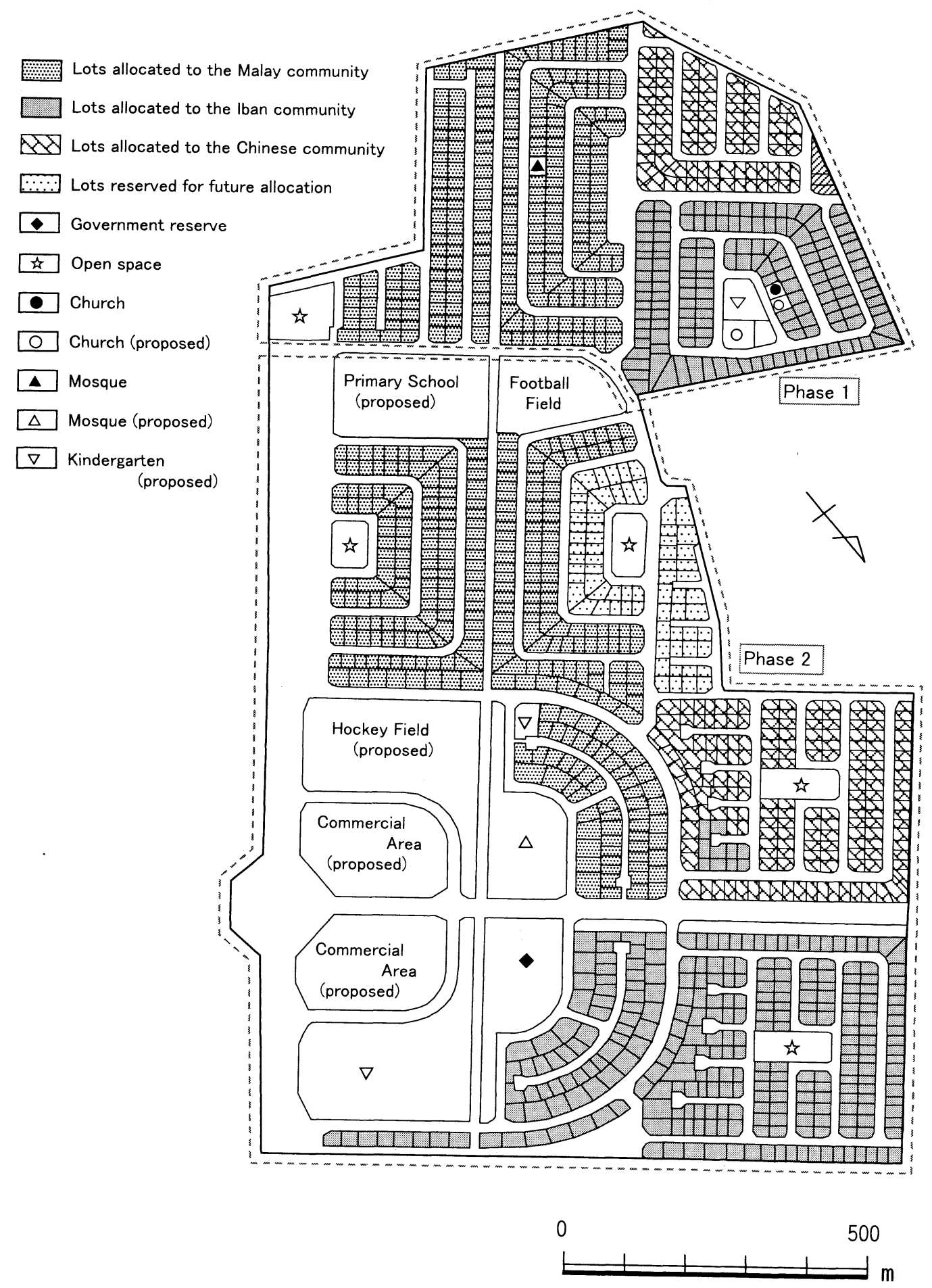

Figure 4. Plan view of Kampung Sentosa resettlement area. 


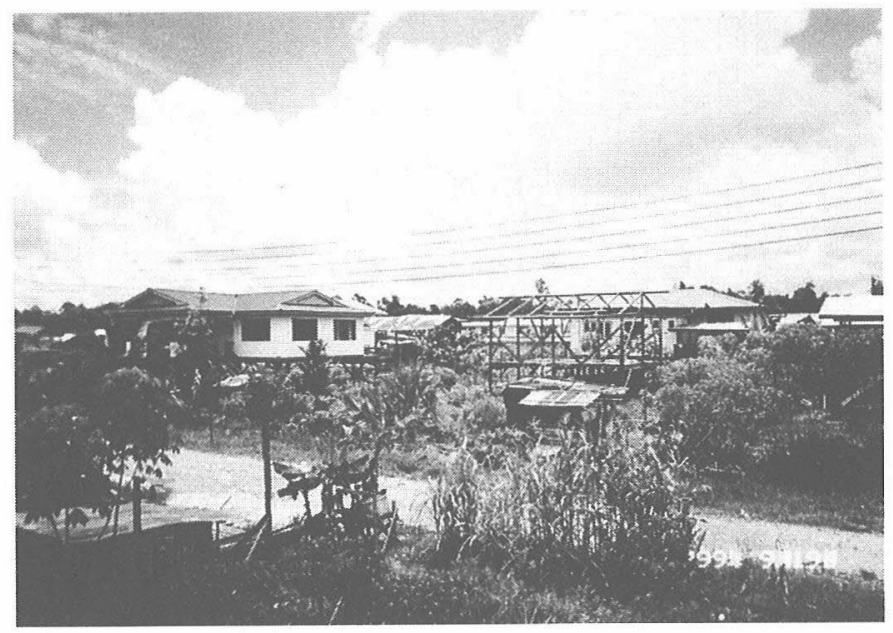

Photo 3. Kampung Sentosa resettlement area (Phase 2).

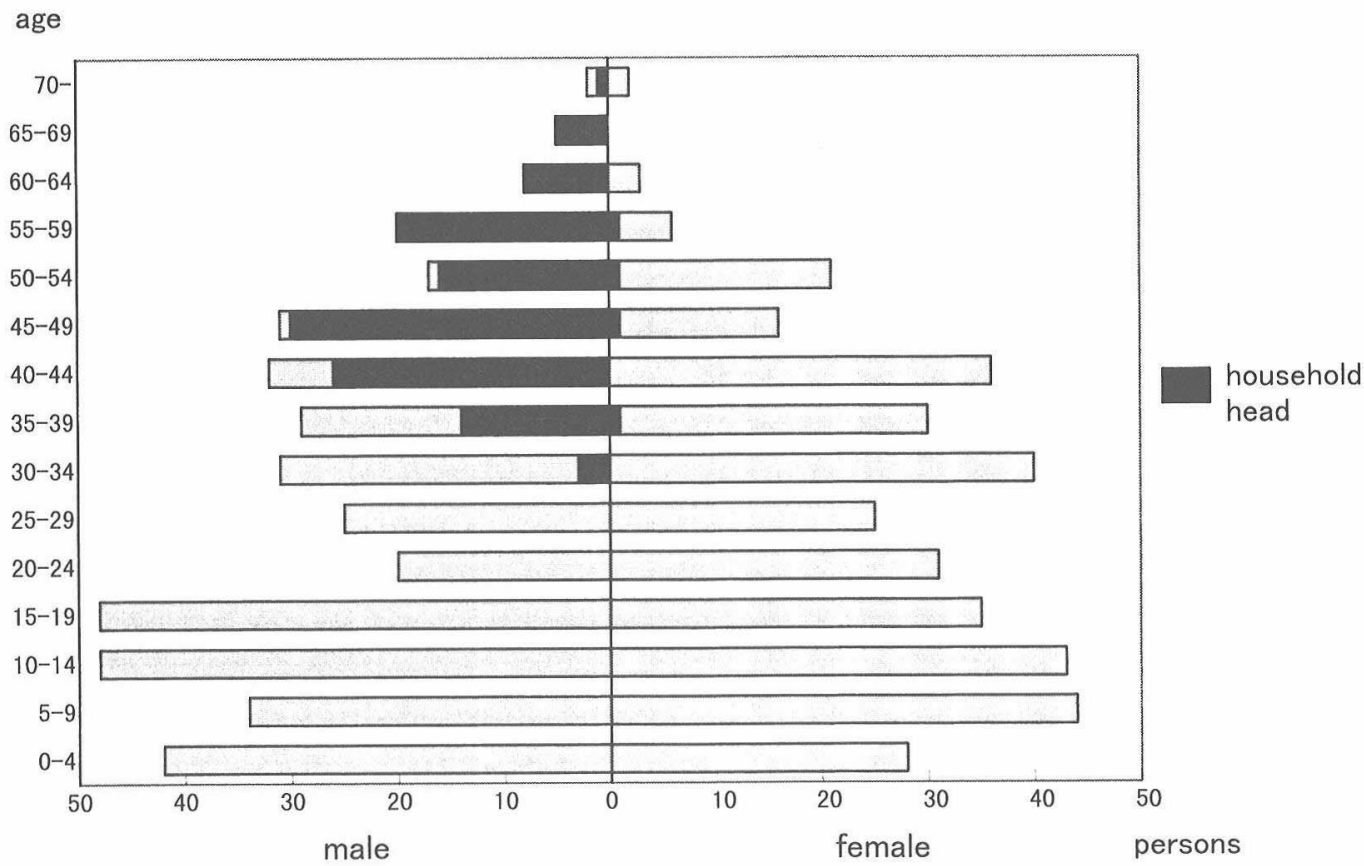

Figure 5. Age structure in Kampung Sentosa (interviewed households).

clerical work as garbage collecting, grass cutting (gardener), road repairing, driver of official vehicles, and office cleaning. As was mentioned earlier, the Iban in Sibu town are convinced that they receive the benefit of the diverse job opportunities under the so-called Bumiputera policy. However, they also nurse a grievance against the Muslim-preference policy which seems to prevent the Iban from being promoted.
Therefore, although the majority of the Iban in $\mathrm{Kg}$. Sentosa are involved in formal sectors, especially in the government sector as lowergrade laborers, there is no doubt that they are part of the low-income group in Sibu town.

The status as government servants, however, ensures their stable income and a pension after retirement. It seems one of their long-term living strategies for establishing their lives in 


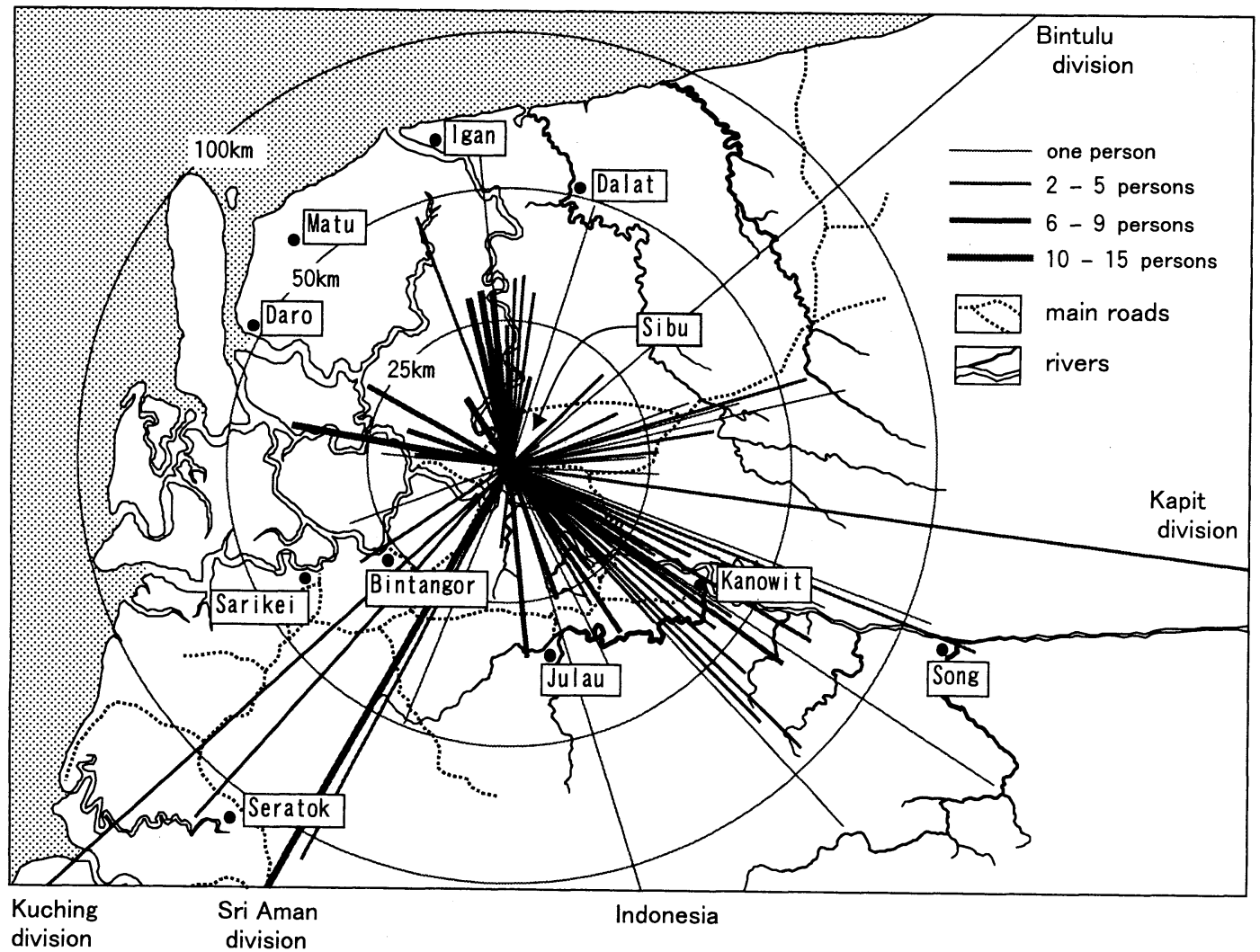

Figure 6. Cluster of home-places of Kampung Sentosa residents.

Sibu town is to try to obtain steadier jobs as lower-level government servants, even with some discontent, rather than to seek for short term higher-wage contract works which are unstable and sometimes involve risks.

\section{Staying rooted in a local town?}

Those who had experienced heavy labor in logging camps or other short term contract works in distant places before settling down in Sibu town amount to $45.5 \%$ of registered household heads. These workers were usually provided with shelter and food, and in most cases the workers went back to their home places when the contract expired. As was pointed out in previous studies (e.g. Jayum 1991; Soda 1999a), it is possible for the Iban to live at subsistence level in rural long-house communities in the middle and lower Rajang basin if they engage in small scale agriculture such as paddy planting. Therefore, there were very few people who continued to stay in urban areas without any job opportunities, and most of the jobless people used to stay in long-houses until their jobs had been definitely arranged. This occurred whether they sought informal jobs through acquaintances who lived in urban areas or tried to find formal jobs which needed written applications or personal interviews. However, once they obtained stable jobs in Sibu town, they began to face the need to find housing.

Though the squatters of defunct Kg. UJ were symbolic of the insecurity of housing in Sibu town, they also displayed shrewdness, as previously stated, in their interaction with the administration to make their urban lives more stable. Moreover, their steadier urban lives in the resettlement area have been reinforced by the improvement of the infrastructure such as the supply of water, electricity, and telephone line at every door or by the public services such as garbage collecting or bus routes.

Former informal people's organizations were 
Table 7. Working situation of current household members in Kampung Sentosa

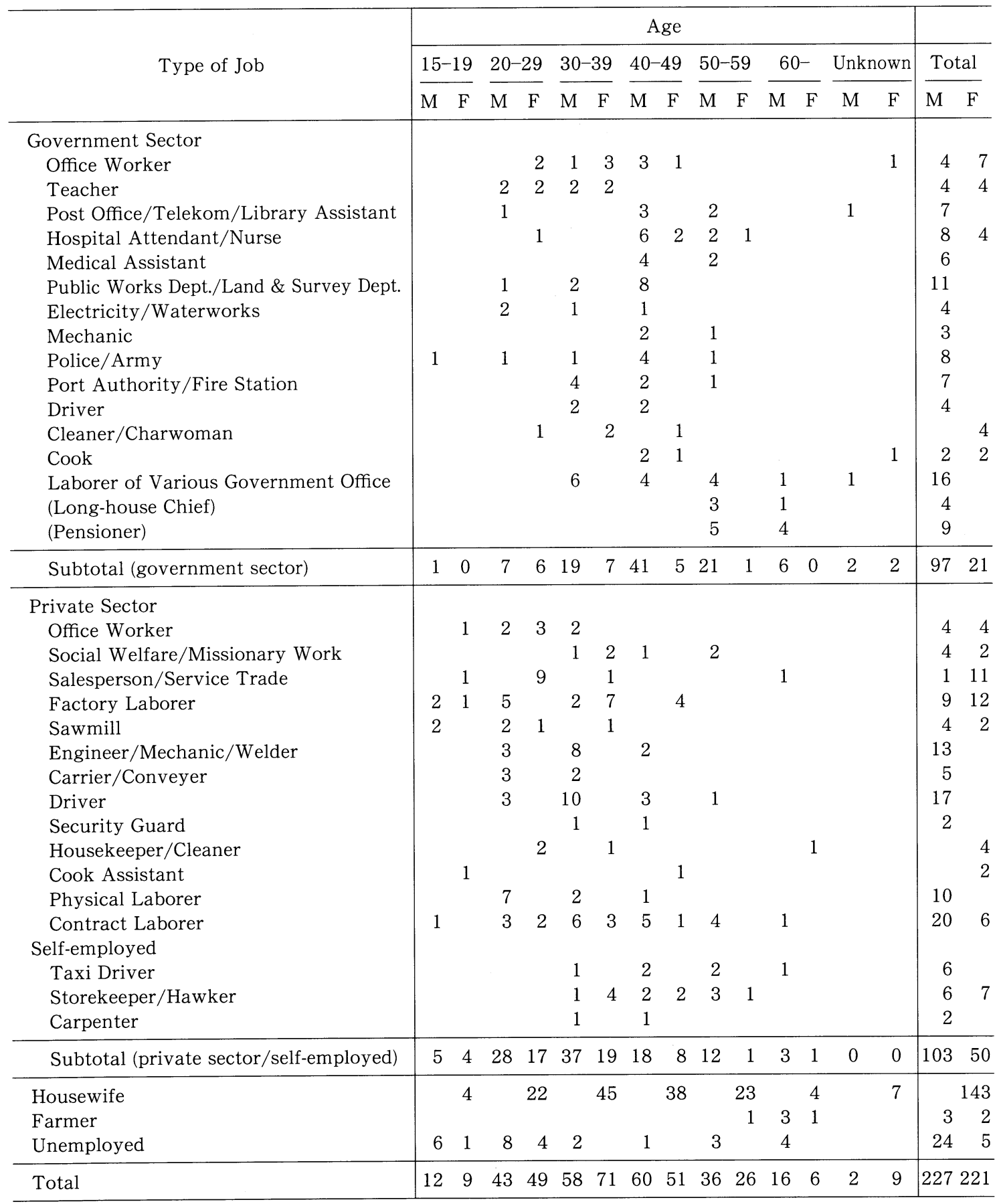

Source: Author's field survey.

reformed to become 'Village Security and Development Committees (Jawatankuasa Keselamatan dan Kemajuan Kampung: JKKK)' which were authorized by the federal government, and each chairperson of the committees was formally registered as 'community chief.' ${ }^{31}$ It cannot necessarily be said that the formation of a formal organization directly affects the inte- 
gration of all the residents, but it plays an important role, at least, to involve the community members more effectively and to keep in contact with the administration.

Thus, by virtue of steadier jobs, living quarters, and the urban public services, or through the formation of formal organizations, the Iban seem to live in Sibu town as 'urbanized people,' not as 'urban villagers.' However, when we reflect on the tendency of the rural-urban migration studies to disregard the movement of migrants into local towns, we have to question again why the migrants have endeavored to settle into a local town. Why is it that the nearest regional center, Sibu town, does not have importance, at least for the Iban, as a transit place to migrate further to larger cities? To answer this, the following chapter will return to the question of whether the stability of their jobs and residence can be a definitive factor for their settling down in Sibu.

\section{Migrant Strategies to Maintain Rural- Urban Linkages}

\section{Intention to return the village of origin}

According to personal interviews with the registered household heads who had been successful in obtaining stable residence in Sibu, $55.3 \%$ of them revealed their intention to return to their home long-houses after retirement, and $14.4 \%$ answered that they would enjoy 'double residence' by spending their time sometimes in Sibu and sometimes in long- houses (Table 8 ). On the other hand, those who have no intention to return to the home village and will stay in Sibu even in their old age are only $17.4 \%$ (12.9\% of them have not yet decided or are reluctant to answer).

The reason for their return to the home is clear. Since they expect that their income will decrease after retirement, it will make it more difficult to remain in the town. They therefore intend to transfer their bases back to longhouses in the future to make a living by small scale agriculture.

To estimate their properties in their longhouse communities, questions were asked as to whether they have their own 'bilek' (family room), which is a domestic, separate room to maintain each household and is one of the inherited properties in a long-house community. The result of the interview was that $82.6 \%$ of them replied that they have a bilek either in their own or their spouses' long-house. Regarding the current dwellers in bilek, however, there is some variety as is shown in Table 9. Those who have exclusive ownership of a bilek through inheritance from their late parents or by constructing a new bilek by themselves are $36.4 \%$, and most of these bilek are empty at present (29.5\%). The bilek in which at least one of their parents lives are $36.4 \%$, while those occupied by their brothers (or sisters) are $8.3 \%$, and other relatives $1.5 \%$.

If a married brother (or sister) lives in a bilek, it is quite likely that (s)he will inherit the bilek, whether his (her) parents are still alive or not. On the other hand, if only parents or their un-

Table 8. Distribution of registered polling places among each household

\begin{tabular}{|c|c|c|c|c|c|}
\hline \multirow[b]{2}{*}{ Plan for the future } & \multicolumn{4}{|c|}{ Voting distribution } & \multirow[b]{2}{*}{ Total } \\
\hline & $\begin{array}{l}\text { Whole membership } \\
\text { of household vote } \\
\text { at long-house }\end{array}$ & $\begin{array}{c}\text { Some of household } \\
\text { members vote at } \\
\text { long-house and } \\
\text { others in Sibu }\end{array}$ & $\begin{array}{l}\text { Whole membership } \\
\text { of household vote } \\
\text { in Sibu }\end{array}$ & Others/Unknown & \\
\hline $\begin{array}{l}\text { Return to long-house } \\
\text { after retirement }\end{array}$ & 38 & 16 & 14 & 5 & 73 \\
\hline "Double residence" & 6 & 12 & 1 & 0 & 19 \\
\hline Stay in town & 0 & 0 & 23 & 0 & 23 \\
\hline Undecided/Unknown & 0 & 3 & 9 & 5 & 17 \\
\hline Total & 44 & 31 & 47 & 10 & 132 \\
\hline
\end{tabular}

Source: Author's field survey. 
Table 9. State of original bilek of Kampung Sentosa residents

\begin{tabular}{cc}
\hline State of original bilek & household \\
\hline Occupants of original bilek & 39 \\
Empty & 9 \\
Double residence & 48 \\
Parent & 11 \\
Brother/Sister & 2 \\
Other relative & 17 \\
Having no bilek in Long-house & 6 \\
Others/Unknown & 132 \\
\hline
\end{tabular}

Source: Author's field survey.

married children are left in a bilek, the heir to the bilek generally has not yet been definitely determined.

Also noticeable is the inheritance of land in their home villages in relation to the inheritance of bilek. Most of the registered household heads (77.3\%) answered to the author's question that they have some parcels of land ${ }^{32}$ either in their or spouses' home village. It should be noticed, however, that if their parents are still alive, such land still belongs to their parents in most cases, and the children are not necessarily guaranteed to succeed parents' land.

A number of previous studies on the land tenure system of the Iban have pointed out the loosely disciplined land holding relevant to the egalitarianism of the Iban society. For example, concerning the fact that disequilibrium of each household's land holding has not brought about the stratification among the Iban society, Padoch (1982) explains that this can be attributed, not only to ecological factors such as relatively low population density and tradition of shifting cultivation, but also to their egalitarianism which was reflected in the frequent land borrowing free of charge. The land borrowing between bilek-families is a good indication of the looseness of their land usufruct and land inheritance. According to the customary law (adat) of the Iban, those who have left their original bilek for matrimony (ngugi/nguai) cannot claim the bilek nor land of their parents. This does not mean, however, that they entirely lose a chance to inherit the land. They are still allowed to beg pieces of land, and the decision of whether or not they are given any parcel of land, and if given how large a piece of the land, depends on their parents and original bilekfamily members (se-bilek). This 'se-bilek' means a family comprised of those who have not left the bilek for marriage and still belong to it regardless of their current place of residence. However, it is pointed out by $\mathrm{Kg}$. Sentosa residents that in general those who remain in longhouse to look after their aged parents will most probably succeed a larger tract of land.

On the other hand, even those who have once left the bilek for marriage can be approved to return to the original long-house or bilek as long as they pay some fine. In addition, if they are considered to have contributed enough to maintain their original bilek or look after their parents instead of brothers (or sisters) who live outside the long-house, it will be easier for them to return to the bilek or claim a relatively larger tract of land without feeling alienated.

Thus, the customs of the Iban are flexible, which is useful for urban dwellers, because their long-term absence from a long-house community can incur the possibility to relatively weaken their various rights as a bilek-family member, while at the same time they can preserve the possibility to return to a bilek or inherit land regardless of their residential places. What is important for them is to maintain intimate and sympathetic relation with long-house community and bilek-family, which may be tacit long-term contract between parents in village and children in town, sometimes through economic aid such as remittances (Stark and Lucas 1988; Hoddinott 1994).

\section{Maintaining relationships with the long-house}

The use of remittances is one of the essential topics when the relationship between urban dwellers and village folk is discussed. Even in Sarawak, a lot of long-house dwellers are economically dependent on their children working in urban areas. According to the personal interviews with $\mathrm{Kg}$. Sentosa residents, 63 household heads still have at least one parent in a long-house. In my survey 52 persons (82.5\%) answered that they give economic assistance to the parents in the long-house; those who send remittance periodically make up only $15.9 \%$ (10 
persons). This means that most household heads hand over cash directly to their parents either when they go back home or when their parents come to the town to visit children.

There are many chances for urban dwellers to go back to long-houses. During the annual festival, Gawai, ${ }^{33}$ most town dwellers return to their long-houses. Apart from Gawai, there are various other reasons, such as funerals, the end of mourning period, the service of exorcism, engagement ceremonies, and wedding receptions. Some people go back to the long-house on the weekend or sometimes take leave to join large-scale group work, attend important meetings, or help their family during the busy farming season. Thus circulatory migration is very common.

The urban-rural relation is not just from urban dwellers to long-house communities. Rituals and other gatherings held in $\mathrm{Kg}$. Sentosa are also in most cases announced to relatives and friends in long-houses. During the agricultural off-season, long-house people sometimes spend their spare time with their children in town. It is much more important for longhouse people to go to town to see a doctor at hospital, visit public offices, draw pensions, and utilize bank accounts. Therefore, it is important for them to have a close relative in town who provides them an urban base and makes it easier for them to visit and stay in town for various purposes.

Through these frequent mutual movements between urban and rural communities, children have many chances to hand over cash directly to their parents, which seems to leave an impression of their sympathetic ties rather than remittance activities.

Apart from the relation between the bilekfamily members, town dwellers also have some obligations to remain long-house community members. As indicated above, those who have an exclusive ownership of a bilek make up $36.4 \%$ of the registered household heads in $\mathrm{Kg}$. Sentosa. Indeed, these people have already been assured of future residence in the longhouse; nevertheless they are also obliged to go back frequently to their long-house. This is because the custom of the Iban does not allow the bilek to be empty for a long time. ${ }^{34}$
These various ways of keeping rural-urban relations can be considered an extremely important strategy of town dwellers to plan their future return to the long-house after retirement. In sum, it is necessary for them to remain accepted as a core member of the long-house community by giving a clear indication that they can contribute to the maintenance of the bilek and the community as well.

As for the issue of the breakaway from a bilek, if one has constructed a new bilek after his (her) marriage, (s)he is considered to have become 'independent (kediri)' of his (her) parents, while to acquire a house in town can be recognized either as 'independent' or still belonging to a bilek according to the consensus between parents and children. ${ }^{35}$ Their judgment may strongly be influenced by their intention, whether to return home or remain in town in the future.

In short, migrants' choice to secure a residence in Sibu town was based on the careful consideration of their position in both rural and urban places as a strategy for their future life.

\section{Voting activities as homecoming preparation}

In this section we would like to discuss the voting activities of the Iban, which can be considered as a form of preparation for their return to the long-house.

In Sarawak, there are two types of public elections. One is the general election for the Parliament of the Federation, and the other is the State Assembly. Both adopt single-member constituency system. In these elections all people 21 years and over are qualified to vote and they can choose their polling place regardless of their current residence.

Table 8 shows the variation of the registered polling places of $\mathrm{Kg}$. Sentosa residents in 1999. Those who have an intention of future return mostly register at a polling place in a village, not in Sibu town. This reflects development politics in Sarawak.

Although the government budget for rural development has been increasing in the last two decades, it has not necessarily been distributed impartially to each district. The fact that the development funds were not allocated to the constituencies in which an opposition 
candidate was elected in the past elections indicates the government's discriminatory treatment between constituencies (Mason 1995). This punitive decision by the government on the funds distribution has already been common knowledge among the Iban.

They are therefore well aware that their support of Government parties can make sure they obtain government subsidies or rural development projects. Moreover, since the 1999 election for the State Assembly the government began to adopt a new ballot-counting system which can find out details of the results in each long-house (Mason 1995). Therefore, it is inevitable for a long-house community to raise the voting rate for the Government parties in order to obtain rural development projects such as the supply of water and electricity, the construction of rural roads, minor bridge-building, or the provision of various kinds of building materials, all of which are indispensable for the improvement of living conditions in a longhouse.

Considering these decision-making processes on the funds distribution for rural development, most of the Kg. Sentosa residents choose to vote in a long-house in order to prepare for a more comfortable life in long-house after retirement.

However, they also pay attention to the expansion of urban amenities or infrastructures in their current residence, Kg. Sentosa. For example, improvement of public transportation, road-pavement in the settlement, construction of assembly hall and religious places (mosques or churches), establishment of primary school and kindergarten, are all dependent on approval and subsidies from the government. It is therefore important for them to show their support of Government parties even in the urban area. Therefore, those who attach importance to the improvement of their urban lives think it necessary to vote also in the urban constituency. This is because $23.5 \%$ of households have a strategy to disperse their voting places to Sibu town and a long-house between husband and wife or parents and children within a household. ${ }^{36}$

In short, their considerable concern both for the present urban life and the future life in a long-house community is clearly reflected in their voting activities.

\section{Conclusion}

To the Iban, Sibu town is a place of the Chinese in the regional context of Rajang basin. At the same time in the national context of Malaysia or Sarawak, it is a place where they first feel frustrated by government policies that give preference to Muslims.

The non-Muslim indigenous in Sarawak are regarded as 'unfortunate poor people who are never able to develop by themselves' as long as they live in villages, and once they migrate into urban areas, they are dealt with as 'problem people' who convey rural poverty into urban areas.' Thus the Iban acknowledge themselves as the 'urban poor.'

In these situations, however, they always seek for strategies to make their urban lives more stable. For example, they prefer to get a steadier job in the government sector, even a relatively unskilled job, squat on government land to obtain a new legal lot, make use of their status as government servants to accumulate useful information, maintain their compromise with other ethnic groups, and make political bargains with local politicians.

Their long-term stay in the urban area, however, does not mean rupture with long-house community, but rather the preparation for a more comfortable future life in long-house. In this paper, we have discussed the manner in which they keep a balance between rural and urban life, remain involved in bilek-family and long-house communities, and make use of politics to lure development projects to longhouses.

These can be said to be the long-term strategies of the 'urban poor' who do not necessarily consider their urban base permanent, but try to establish their homes in different places with an eye to the life cycle. In this sense, it was significant for them to make a choice of their urban residence in a local town which is relatively near to the long-house of origin. Thus, the meaning of their urban residence is far different from that of 'bejalai' custom (male's journey to obtain wealth or fame by himself or 
in a small group).

So far, there has been little research on poor in-migrants in local towns. If the characteristic of a local town can be attributed to a part of its population who sustain solid connection with the communities in the hinterland, and maintain frequent and mutual mobility between urban and rural areas, it becomes more important to see a local town and its hinterland as a cultural ecological unit. In other words, this paper makes this possible, by observing various aspects of the activities of the urban poor in a local town, or by clarifying their living strategies to reinforce rural-urban relations, which has been ignored by research conducted in larger urban areas.

It will be also necessary for the urban administration to take a wider view of a local town and its hinterland and to present comprehensive development programs designed to bring about closer integration between urban and rural areas.

In the study area, Sibu town, the squatter problem seems to have been resolved at present because of large-scale resettlement schemes put in place since the 1980s. The administration, however, does not deny that squatters may probably increase again in the near future, and feels challenged by this prospect.

The Sarawak government has already disclosed that the government would stop giving out land lots with TOL through its resettlement scheme during the 8th Malaysia Plan, and instead would give priority to the construction of low-cost housing schemes. However, the standard price of a low-cost house recently offered for sale in Sibu is 32,000RM and above, which is still so expensive that lower-income people such as Iban cannot afford even such a low-cost house. This policy conversion of Sarawak government is a noteworthy matter which may well be repeating the failure of housing policy in peninsular Malaysia in the 1970s.

In all cases, the problem of finding housing will be harsher for those who intend to migrate into urban areas in future. What is more, if we take into account the increase of urban-born population who have never experienced life in long-house, or the prospective shortage of land for small-scale agriculture because of the ex- pansion of commercialized plantations, the prevalent idea that one can contrive to make a living in long-house even if (s)he fails in town seems unlikely. These changes may offer new dimensions in the population mobility between local towns and their hinterlands. Future investigation needs to clarify this situation for local administrations, the urban poor, and longhouse dwellers so that they can more effectively solve these emerging problems.

\section{Acknowledgements}

I would like to express my gratitude to Prof. Dr. Terry G. McGee, University of British Columbia for beneficial comments during the preparation of the English manuscript. Thanks are also due to Prof. Dr. Hiroshi Ishihara, Kyoto University, who gave me a lot of important suggestions. This research project was realized thanks to Dr. Peter Kedit, ex-director of Sarawak Museum and Dr. Daniel Chew, senior research fellow of Sarawak Development Institute. In addition, appreciation is given to Datin Fransisca Sadai binti Udang, Mr. Fabian Ajah Saging, and many other friends in the study area, without whose help this paper would have been impossible. This study was financially supported in part by Japan Society for the Promotion of Science (1998-1999, No. 3353).

(Received Jul. 3, 2000)

(Accepted Oct. 7, 2000)

\section{Notes}

1. In this paper the author defines a 'local city/ town' as a regional center to set it over against primate cities and their satellite cities which have larger socio-economic importance in the national context.

2. Dwyer (1975) pointed out that the definition of 'illegal settlement' may depend on arbitrary judgment where the governmental legal system was incomplete or where customary laws of plural ethnic groups were interwoven with each other. Therefore, he advocated the use of 'spontaneous settlement' in substitution for 'squatter settlement' which lays stress on its 'illegality.'

3. Even within geographical study we can find vast literatures on Southeast Asian cities (e.g. McGee 1967, 1971, 1975; Dwyer 1975; Hugo 1981, 1983; Drakakis-Smith 1987; McGee and Robinson 1995).

4. The emergence of the urban poor and the accumulation of its study are preceded in Latin American countries. 
5. The marginality theory of the urban poor emerged from the study of Latin American cities, which subsequently led to lively discussions on the urban poor in Latin America. The details of the discussion are well explained in Yonemura (1991b).

6. In the field of social anthropology, since the appearance of Radcliffe-Brown and EvansPritchard, an individual had been recognized as being structurally involved in a society and controlled by it. In the same way, the urban poor and their social networks established in urban areas were regarded as the extension of the social relations that had been traditionally constructed in their home villages. It was not until the 1970s that, apart from such classical structuralism, a new viewpoint was proposed that urban in-migrants were enclosed within another structure such as a state or the modern world system. These advocacies were flourishing particularly in the field of urban anthropology in Africa (Matsuda 1990).

7. The conceptualization of the existence of the urban poor such as 'peasants in cities' or 'marginal man' is a good example (see Mangin 1970; McGee 1973; Roberts 1978; Fujimaki 1993).

8. For instance, see Kato (1986), Stark and Lucas (1988), Zenno (1994), Firman (1994), Erman (1998), Hataya (1999), Matsuda (1998).

9. In the 1960s Malaysian government, indeed, began to newly create so-called 'New Towns' which were intended to ease the overconcentration of population into Kuala Lumpur metropolitan area and to create new labor opportunities in rural areas, but the government did not propose any policy on existing local cities and towns (Lee 1987). In Sarawak, on the other hand, the local government has designated several local towns as 'Rural Growth Centers' and declared to redevelop such existing local towns to ease migration to urban centers. These development schemes, however, have been launched so recently (1991) that it is difficult to judge their potential.

10. On the matter of the peripheral situation of Sarawak in the national context of Malaysia, see King (1988, 1990).

11. The population is comprised of Iban (29.4\%), Chinese (27.2\%), Malay (21.3\%), Bidayuh (8.3\%), Melanau (5.7\%), and other small indigenous groups which are not identified in the 1991 census.

12. 'Bumiputera Policy' is officially called 'New Economic Policy.' See note 19.

13. An article reported that an Iban man in peninsular Malaysia was not approved as a Bumiputera, which was closely related to his background of Sarawak origin and his Christianity (Far Eastern Economic Review, June 12,
1997: 27).

14. How the urban poor themselves recognize their situation of 'double marginality' will be discussed in detail in a forthcoming article.

15. The Foochow are now the second largest Chinese dialect group in Sarawak.

16. Strictly speaking, non-Bumiputera includes Indian, Indonesian, and other small groups besides Chinese, and non-Muslim Bumiputera includes Bidayuh, Kayan, Kenyah, Christian Melanau, and so on. In the administrative reports in Sibu, however, details of ethnic groups are not specified, but the terms, Chinese, Malay/Melanau, and Iban are used to be synonymous with non-Bumiputera, Muslim Bumiputera, and non-Muslim Bumiputera. To avoid these intricacies this paper follows the terminology of the administrative reports.

17. This is according to the interview with a staff of Enforcement Section, the Land and Survey Department (Sibu Branch).

18. According to the report prepared by the Land and Survey Department in 1983, 57\% of Bumiputera were employed in the government sector even though the report did not distinguish between the Iban and the Malay (Land and Survey Department, Sibu Branch, Annual report 1984).

19. The main purposes of New Economic Policy were two-fold. The first purpose was to eradicate poverty, and the second was to reorganize Malaysian society so that the Bumiputera could have a more equal participation in Malaysian economy. In this policy, various kinds of preferential treatment were given to the Bumiputera. The New Economic Policy was completed in 1990 and succeeded by National Development Policy between 1991 until 2000. Although this policy does not express its purpose numerically as in the New Economic Policy (e.g. New Economic Policy specified the target to raise the capital holding rate of the Bumiputera up to $30 \%$.), the basic line of the Bumiputera-preferred policy has continued. Therefore, so long as the 'Bumiputera Policy' is understood as general measures adopted to raise Bumiputera's economic status since the New Economic Policy, the government policy since 1991 also can be recognized as a type of Bumiputera Policy.

20. This means that local towns in Sarawak, too, have been expanding to lead various development programs into the fringe of urban areas. Concerning $\mathrm{Kg}$. UJ settlement, squatter clearance was propelled for the purpose of the construction of an exclusive residential district with Chinese-based capital.

21. However, any clear criterion to approve an application was not specified. 
22. One Ringgit Malaysia was approximately equal to 0.37 US dollars as of 1991.

23. According to the Land Law of Sarawak state, the whole land of Sarawak belongs to the state. Therefore, so-called land title means the rights to lease the state land. The period of the lease is limited to within 60 years, which can be renewed to extend the period.

24. This is according to the interview with the chairman of JKKK of the Iban area in Phase 1 and a staff of Enforcement Section, Land and Survey Department (Sibu Branch).

25. For example, the average number of households (bilek-families) in a long-house is 18.1 (Sibu District Office, Senarai ketua-ketua masyarakat dan ketua-ketua kaum di daerah Sibu 1999). Similarly, the average number of bilek families in a long-house in Kanowit district, a neighboring district to Sibu district, is 17.9 (Kanowit District Office, Senarai ketua kaum di bawah bidangkuasa ketua masyarakat daerah Kanowit 1996). As long-houses began to take on the character of permanent residence and the population of long-house community increased naturally, there have emerged fairly large communities and now it is not strange for a village community to have plural longhouses. However, it is still seldom to find a village which contains more than 200 bilek families.

26. The details of their political activities and its meanings will be discussed in a forthcoming article.

27. The reason why the construction of their houses is seriously delayed is that most of the residents cannot afford to employ professional carpenters. They themselves are engaged in construction, and can only scrape up the cost of constructing their houses little by little. Some people live in rented rooms in urban centers until their houses in $\mathrm{Kg}$. Sentosa are built. That is why even the Land and Survey Department does not grasp how many people really live in $\mathrm{Kg}$. Sentosa at the present time.

28. In this paper, conjugal family means a family comprised of a conjugal couple and their unmarried children, and stem family means that including a conjugal couple of a child of the household head. A joint family contains more than two conjugal couples within a same generation.

29. Even those who were in secondary schools in Sibu town mostly returned to their original long-houses after graduation. Incidentally, there are four registered household heads who were born in town and have never lived in the long-house community.

30. Those over 15 years old except for school attendants are counted.
31. In Kg. Sentosa every ethnic group in Phase 1 and Phase 2 has its own JKKK organization individually and each JKKK has a chairperson (chief). It was not until the end of 1999 that JKKK of the Iban area in Phase 1 was first registered belatedly because there had been repeated inefficient handling in the process of formal registration.

32. Most of the land that is said to be held in the village is so-called 'Native Customary Rights Land,' which has no registered land title. See Soda (1999b) for the perception of land holding among the Iban society.

33. In Sarawak state, the first to the third of June are public holidays for Gawai festival.

34. According to the customary law of the Iban, each household is obliged to use the kitchen in their own bilek (called nungkun dapor). When they cannot discharge this duty, they are compelled to pay a penalty to the head of longhouse community. Although the amount of penalty varies from one long-house to another, they are usually fined ten to fifty Ringgit Malaysia and a chicken.

35. If they have a stable residence in urban areas, they are said to 'idup kediri,' which means 'to make own living' or 'to live independent economically.' However, this does not necessarily mean their secession from their original bilekfamily (se-bilek).

36. Close observation of the voting activities of the Iban in Kg. Sentosa reveals the variety of more conscious and strategic movement. Such various voting activities are closely related to the distribution of development programs in Sarawak and the electoral strategies of the parties and politicians who practically control the development programs. This paper does not deal with this matter owing to limited space. See a forthcoming article.

\section{References}

Butterworth, D. R. 1970. A study of the urbanization process among Mixtec migrants from Tilantongo in Mexico City. In Peasants in cities: Readings in the anthropology of urbanization, ed. M. Mangin, 98-113. Boston: Houghton Mifflin.

Drakakis-Smith, D. 1987. The third world city. London: Methuen.

Dwyer, D. J. 1975. People and housing in Third World cities. London: Longman.

Erman, T. 1998. Becoming "urban" or remaining "rural": The views of Turkish rural-to-urban migrants on the "integration" question. International Journal of Middle East Studies 30: 541-561.

Firman, T. 1994. Labour allocation, mobility, and remittances in rural households: a case from Central Java, Indonesia. Sojourn 9: 81-101. 
Fujimaki, M. 1993. A review on studies of "urban villagers' in the developing countries. Tenri University Journal 174: 31-49. (J)

Hart, K. 1973. Informal income opportunities and urban employment in Ghana. Journal of Modern African Studies 11: 61-89.

Hataya, N. 1999. Introduction. In Urban people's organization in developing countries: Its role for social development, ed. N. Hataya, 3-28. Tokyo: Institute of Developing Economies. (J)

Hoddinott, J. 1994. A model of migration and remittances applied to western Kenya. Oxford Economic Papers 46: 459-476.

Hugo, G. J. 1981. Village-community ties, village norms and ethnic networks: a review of evidence from the Third World. In Migration decision making: Multidisciplinary approaches to microlevel studies in developed and developing countries, ed. G. F. De Jong and R. W. Gardener, 186-224. New York: Pergamon Press.

Hugo, G. J. 1983. Population mobility and wealth transfers in Indonesia and other Third World societies. Honolulu: Papers of the East-west Population Institute, No. 87.

Jagannathan, N. V. 1987. Informal markets in developing countries. New York: Oxford University Press.

Jayum, A. J. 1991. The ethnic factor in modern politics: the case of Sarawak, East Malaysia. Hull: Center for South-East Asian Studies at The University of Hull, Occasional Paper No. 20.

Kato, T. 1986. Urban ethnicity in Indonesia: networks and locality-based associations. Southeast Asian Studies (Kyoto) 23: 391-418. (JE)

King, V. T. 1988. Models and realities: Malaysian national planning and East Malaysian development problems. Modern Asian Studies 22: 263298.

King, V. T. 1990. Why is Sarawak peripheral? In Margins and minorities: The peripheral areas and peoples of Malaysia, ed. V. T. King, 110-129. Hull: Hull University Press.

Kumagai, K. 1990. Jakarta no "nijuu kouzou" to sono hennyou: Informal sector to kampung wo megutte. In Henbou suru Asia: NIEs/ASEAN no kaihatsu to chiiki hennyou, ed. Asia chiri kenkyuukai, 123-173. Tokyo: Kokon Shoin. (J)

Lee, B. T. 1987. New towns in Malaysia: development and planning policies. In New towns in East and South-east Asia, ed. D. R. Phillips and A. G. O. Yeh, 153-169. Hong Kong: Oxford University Press.

McGee, T. G. 1967. The southeast Asian city: A social geography of the primate cities of Southeast Asia. London: G. Bell and Sons.

McGee, T. G. 1971. The urbanization process in the Third World: Exploration in search of a theory. London: G. Bell and Sons.

McGee, T. G. 1973. Peasants in the cities: A paradox, a paradox, a most ingenious paradox. Human
Organization 32: 135-142.

McGee, T.G. 1975. Malay migration to Kuala Lumpur city: Individual adaptation to the city. In Migration and urbanization: Models and adaptive strategies, ed. B. M. Dutoit and H. I. Safa, 143178. Hague: Mouton Publishers.

McGee, T. G. and Robinson, I. M. eds. 1995. The mega-urban regions of Southeast Asia. Vancouver: University of British Columbia Press.

Mangin, W. ed. 1970. Peasants in cities: readings in the anthropology of urbanization. Boston: Houghton Mifflin Company.

Mason, R. 1995. Parti Bansa Dayak Sarawak and the Sarawak state elections of 1987 and 1991. Kajian Malaysia 13(1): 26-58.

Matsuda, M. 1990. Restriction and creation: Urban emigration in Kenya: a case study. Journal of Historical Studies 612: 31-43. (J)

Matsuda, M. 1998. Urbanization from below: Creativity and soft resistance in the everyday life of Maragoli migrants in Nairobi. Kyoto: Kyoto University Press.

Nakanishi, T. 1988a. The urban informal sector in the Philippines (I). Monthly Journal of Institute of Developing Economies 29(1): 17-33. (J)

Nakanishi, T. 1988b. The urban informal sector in the Philippines (II). Monthly Journal of Institute of Developing Economies 29(2): 48-62. (J)

Niitsu, K. 1989. Josyou: Gendai Asia ni okeru slum mondai no syozai. In Gendai Asia no slum: Hatten tojoukoku toshi no kenkyu, ed. K. Niitsu, 16-91. Tokyo: Akashi Shoten. (J)

Padoch, C. 1982. Migration and its alternatives among the Iban of Sarawak. Hague: Martinus Nijhoff.

Perlman, J.E. 1976. The myth of marginality: Urban poverty and politics in Rio de Janeiro. Berkeley: University of California Press.

Roberts, B. 1978. Cities of peasants: The political economy of urbanization in the Third World. London: Edward Arnold.

Soda, R. 1999a. Rural-urban migration of the Iban of Sarawak and changes in long-house communities. Geographical Review of Japan 72A: 122. (JE)

Soda, R. 1999b. The evolving concept of land ownership among the Iban of Sarawak, Malaysia. Human Geography 51: 1-23. (JE)

Stark, O. and Lucas, R. E. B. 1988. Migration, remittances, and the family. Economic Development and Cultural Change 36: 465-481.

Sutlive, V. H. 1992. The Iban of Sarawak: Chronicle of a vanishing world. Kuala Lumpur: S. Abdul Majeed \& Co.

Tokman, V.E. 1978. An exploration into the nature of informal-formal sector relationships. World Development 6: 1065-1075.

Wazaki, H. 1988. The essence of the city from the urban anthropology view point. Journal of $\mathrm{Mu}$ nicipal Problems 40(2): 79-95. (J) 
Yamazaki, H. 1978. Toshi bakuhatsu to noumin rison. In Gendai daitoshi no kouzou, ed. K. Yoshioka and H. Yamazaki, 269-301. Tokyo: Tokyo University Press. (J)

Yonemura, A. 1991a. Process and backgrounds of paradigm change in Latinamerican urban poor studies: From modernization theory to dependency theory (I). Monthly Journal of Institute of Developing Economies 32(4): 2-13. (J)

Yonemura, A. 1991b. Process and backgrounds of paradigm change in Latinamerican urban poor studies: From modernization theory to dependency theory (II). Monthly Journal of Institute of
Developing Economies 32(5): 28-47. (J)

Yoneyama, T. 1987. Daisan sekai ni miru toshi no hougateki keitai. Syunjuu Seikatsugaku 1: 202210. (J)

Zenno, M. 1994. The inter-relationship of the social organizations of rural villagers and urban migrants: A case study of a village in Oxaca, Mexico. Japanese Journal of Ethnology 59: 193220. (JE)

$(\mathrm{J})$ : written in Japanese

(JE): written in Japanese with English abstract 